\title{
JURNAL PARIWISATA PESONA
}

Volume 6 No 1, Juni 2021: p 81 - 94

Print ISSN: 1410-7252 | Online ISSN: 2541-5859
DOI: https://doi.org/10.26905/jpp.v6i1.5543 Homepage: http://jurnal.unmer.ac.id/index.php/jpp/

\section{IMPLEMENTASI PERAN STAKEHOLDERS \\ DALAM PENGEMBANGAN PARIWISATA \\ (Studi Kasus pada Kepulauan Banda)}

\author{
Elvis Salouw
}

Program Studi Pariwisata, Institut Teknologi dan Bisnis Kristen Bukit Pengharapan Jl. Grojogan Sewu, Kalisoro, Kec. Tawangmangu, Kabupaten Karanganyar, Jawa Tengah

\section{Informasi Artikel}

Dikirim: 4 Juni 2021

Diterima: $\quad 28$ Juni 2021

\section{Korespondensi pada penulis :}

\section{Telepon:}

082122727114

Email:

elvisalvred@gmail.com

\begin{abstract}
Banda Islands, also known as the "Spice Islands", is a group of spice-producing islands located in central Maluku District. The Banda Islands are included in the UNESCO tentative list as the World Heritage Centre with the criteria (iv), (vi), (x). Banda islands are also included in the National Tourism Destination (DPN) Maluku province and one of the National Tourism Development Area of Indonesia (KPPN). Banda Islands as a tourist destination has been known for a long time because of the diversity of attractions. However, in its development, tourism in the Banda islands has not shown significant results in the last decade. The management of the Banda Islands tourism involves many actors both from the government, private and community sectors. This study was conducted to find out 1) the development of the Banda Islands Tourism Management, 2) identify the participating stakeholders, 3) know the role of each stakeholders and 4) describe the collaboration between stakeholders in Banda Islands Tourism Management. This research uses qualitative methods, primary data collection is done by observation, interviews and Focus Group Discussion (FGD). The selection of respondents in the interview is determined purposive sampling based on consideration and capacity in the tourism management of Banda District. The data analysis technique used in this study is a qualitative descriptive analysis used to qualitatively describe the data obtained from the research site. The results shows that 1) Coordination between stakeholders has not been well so that the role of each stakeholder in tourism management has not shown maximum results, 2) The role of the private sector is too. so that the tourism development carried out by the public sector has not worked well.
\end{abstract}

Keywords: Banda; Destination; Islands; Stakeholders; Tourism

\section{PENDAHULUAN}

Pariwisata merupakan industri yang paling cepat perkembangannya di dunia (UNWTO, 2018; WTCC, 2019). Pada lingkup Asia Tenggara, Indonesia merupakan negara dengan pertumbuhan pariwisata paling cepat (WTCC, 2019). Saat ini, sektor pariwisata menjadi salah satu sektor penyumbang devisa terbesar bagi negara Indonesia. Pada tahun 2019 presiden Indonesia, Joko 
Widodo menargetkan sektor pariwisata mampu menyumbang 20 miliar dolar AS dari 20 juta kunjungan wisatawan mancanegara (RPJMN, 2020).

Kepulauan Banda lebih dikenal dengan nama "Banda Neira" merupakan salah satu dari 17 kecamatan yang terletak di kabupaten Maluku Tengah. Kecamatan Banda terdiri dari 11 pulau vulkanik, 6 diantaranya sudah berpenghuni sedangkan 5 lainnya belum berpenghuni (Kecamatan Banda dalam Angka, 2017). Kepulauan Banda secara geografis terletak pada posisi: $5^{\circ} 43-6^{\circ} 31$ Lintang Selatan dan $129^{\circ} 44-130^{\circ} 04$ Bujur Timur. Banda sejak dulu dijuluki sebagai 'kepulauan rempah" karena merupakan kepulauan penghasil rempah-rempah serta menjadi sentra perdagangan rempah di Indonesia pada era Kolonialisme.

Kepulauan Banda berperan penting dalam kepariwisataan Indonesia, khususnya Propinsi Maluku. Kepulauan Banda merupakan calon situs warisan budaya dunia campuran UNESCO (UNWTO tentative list) selain itu, Kepulauan Banda juga merupakan salah satu Destinasi Pariwisata Nasional (DPN) yang terdapat di Provinsi Maluku serta masuk dalam Kawasan Pengembangan Pariwisata Nasional (KPPN) Bandaneira dan sekitarnya (Pemerintah Provinsi Maluku, 2018).

Secara umum, Kepulauan Banda 22 destinasi wisata sejarah, 8 destinasi wisata bahari, 4 destinasi budaya, 2 destinasi wisata alam serta 3 destinasi wisata khusus (Kecamatan Banda Dalam Angka, 2017). Bungin (2010), dalam bukunya Destinasi Banda Neira: brand pariwisata Indonesia Timur menggambarkan dengan gamblang potensi pariwisata yang ada di Kepulauan Banda. Meskipun Kepulauan Banda memiliki sejumlah potensi wisata yang menjanjikan, hingga saat ini objek yang dikembangkan hanya wisata sejarah, wisata bawah laut dan wisata budaya (Bungin, 2010). Dengan Potensi wisata yang berlimpah, Kepulauan Banda diharapkan mampu menarik wisatawan datang ke Maluku, baik wisatawan nusantara maupun wisatawan mancanegara.

Hingga saat ini, berbagai upaya telah dilakukan oleh pemerintah untuk mempromosikan pariwisata Banda. Beberapa kegiatan baik skala nasional maupun skala internasional telah dilakukan guna mempromosikan pariwisata Banda pasca kerusuhan 1999 di provinsi Maluku. Salah satu event internasional terbesar yang pernah diselenggarakan adalah Sail Banda pada tahun 2010. Dengan tema "Small Islands for Our Future" sail Banda diikuti oleh 22 negara dengan perwakilannya masingmasing. Event yang diprakasai oleh Kementerian Kelautan dan Perikanan (KKP) bertujuan untuk memperkenalkan wisata bahari yang terdapat di provinsi Maluku, khususnya Kecamatan Banda. Dengan diadakannya kegiatan bertaraf internasional, pemerintah mengharapkan pariwisata Banda lebih dikenal oleh wisatawan mancanegara. Pada kenyataannya, kunjungan wisatawan mancanegara hanya meningkat pada momen event tersebut, jumlah kunjungan wisatawan kembali menurun setelah perhelatan event tersebut. Sebagai contoh, pada tahun 2010 kunjungan wisatawan mancanegara mencapai 3.353 orang pada event sail Banda, tahun setelahnya kunjungan wisatawan kembali menurun (Dinas Kebudayaan dan Pariwisata Provinsi Maluku, 2015).

Selain peran masyarakat dan pemerintah, sektor swasta juga memiliki peran dan kontribusi dalam perkembangan pariwisata Banda. Yayasan Warisan dan Budaya Banda merupakan salah satu bentuk kontribusi pihak swasta terhadap pengembangan pariwisata Banda. Yayasan Warisan dan Budaya Banda didirikan oleh Des Alwi, salah satu pemimpin adat Banda. Tujuan mendirikan Yayasan Warisan Budaya Banda adalah untuk menjadi titik awal restorasi bangunan warisan budaya yang terdapat di Kecamatan Banda (Wrangham, 1999). Peran pemerintah merupakan aspek yang sangat penting dan kompleks dalam pariwisata (Lickorish, Jefferson, Bodler, \& Jenkins, 1994). Akses besar yang dimiliki pemerintah sebagai pembuat kebijakan sangat berpengaruh pada perkembangan suatu destinasi. Selain pemerintah, swasta juga memiliki peran dalam pengelolaan pariwisata. Sektor swasta dalam pariwisata sebagai pemodal, penyedia sarana hiburan serta pendukung sarana transportasi (Lickorish, 1994).

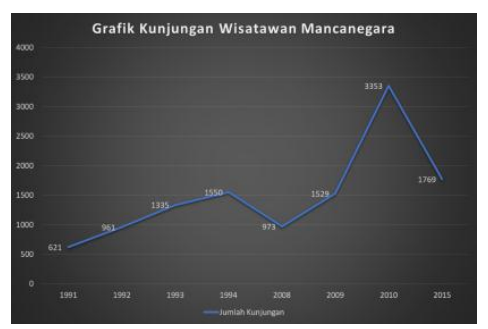

Gambar 1. Kunjungan Wisatawan Mancanegara ke Banda dalam 5 Tahun Terakhir Sumber: Diolah dari UPT Pariwisata Banda, 2019 
Masyarakat sebagai pihak yang terlibat dalam pengelolaan pariwisata juga memiliki andil dalam perkembangan sebuah destinasi. Dalam penelitian yang dilakukan oleh Risakotta (2016), dikemukakan bahwa perkembangan pariwisata Kecamatan Banda sangat dipengaruhi oleh peran pemerintah, namun peran masing-masing aktor serta kontribusinya dalam pengelolaan pariwisata perlu diteliti lebih lanjut. Praktik monopoli pihak swasta dalam sektor pariwisata Kecamatan Banda seperti yang disampaikan oleh Wrangham (1999), dalam penelitiannya yang berjudul Planning tourism in the Banda Islands, Eastern Indonesia berdampak secara langsung terhadap perkembangan pariwisata Kecamatan Banda. Berdasarkan paparan diatas, keterlibatan banyak aktor baik dari sektor pemerintah, swasta, maupun masyarakat memiliki kekuatan dan kelemahan masing-masing sehingga peran tiap aktor perlu dipelajari melalui sebuah penelitian. berikut:

Goeldner \& Ritchie (2012), memberikan defenisi terkait stakeholders pariwisata sebagai

"Tourism may be defined as the sum of the processes, activities, and outcomes arising from the relationships and the interactions among tourists, tourism suppliers, host governments, host communities, and surrounding environments that are involved in the attracting, transporting, hosting and management of tourists and other visitors".

Secara garis besar dijelaskan bahwa pariwisata adalah sejumlah proses kegiatan yang muncul dari adanya interaksi antar stakeholders terkait. Stakeholders yang dimaksud antara lain: pemerintah, pemasok pariwisata, komunitas tuan rumah, dan lingkungan sekitar yang terlibat dalam manajemen wisatawan dan pengunjung lainnya. Selanjutnya, Weaver dan Lawton (2010), memperjelas bahwa "surrounding Environment" yang dimaksud oleh Goeldner dan Ritchie termasuk didalamnya pemerintah daerah di wilayah asal, institusi pendidikan, organisasi non pemerintah (LSM), serta semua pemangku kepentingan terkait pariwisata (Goeldner \& Ritchie, 2012; Weaver \& Lawton, 2010).

Dalam perencanaan pariwisata, sangat penting untuk melibatkan stakeholders yang terlibat maupun terdampak pariwisata (William C. Gartner, 1996; Williams, Penrose, \& Hawkes, 1998). Keterlibatan multi-stakeholder dengan masing-masing kekuatan dan kelemahannya menambah kompleksitas pengorganisasian namun pada sisi lain, dapat memberikan win-win solutions (Bjärstig \& Sandström, 2017; Nuryanti \& Hwang, 2002). Stakeholders merupakan individu atau kelompok perencana dalam pembangunan (Crosby \& Bryson, 1992; Freeman, 1984; Savage et al., 1991).

\section{METODE}

Untuk mencapai tujuan penelitian, metode yang digunakan adalah kualitatif dengan pendekatan studi kasus dan interpretasi sejarah kawasan banda pada masa lalu. Penelitian kualitatif menurut Creswell, (2014) adalah suatu pendekatan untuk memahami serta mengeksplorasi manfaat serta fungsi individu atau kelompok dalam sebuah lingkup permasalahan. Pada penelitian ini, pendekatan yang dilakukan adalah pendekatan studi kasus. Studi kasus adalah salah satu jenis pendekatan kualitatif untuk menelaah sebuah "kasus" dalam suatu setting kehidupan nyata kontemporer (Creswell, 2013).

Data primer penelitian diperoleh dari pengamatan lapangan, wawancara setiap stakeholder serta data sekunder berupa data spasial, gambar, peta serta perundang-undangan. Pengambilan data dilakukan pada bulan januari tahun 2019 untuk kemudian dilakukan pengelompokan data serta analisis. Analisis menggunakan analisis spasial, triangulasi data serta penjelasan naratif.

Teknik pemilihan responden dalam penelitian dilakukan dalam dua tahap. Pertama, dilakukan pendataan terhadap semua stakeholders yang terkait dalam pengembangan pariwisata Banda, selanjutnya dilakukan pemilihan secara purposive sampling terhadap stakeholders yang ada untuk dijadikan sebagai responden atau sumber data dalam penelitian. Responden yang dipilih adalah stakeholders yang dianggap mewakili setiap komponen yaitu masyarakat, swasta dan pemerintah. Responden dari sektor swasta adalah pelaku bisnis pariwisata, pemilik akomodasi, serta akademisi. Responden pemerintahan adalah perwakilan dinas pariwisata Maluku Tengah, UPT Pariwisata Kecamatan Banda, Pemerintah Kecamatan Banda, pihak Kelurahan serta raja Negeri yang ada di 
Banda. Sedangkan pihak masyarakat yang dipilih sebagai responden adalah tokoh masyarakat, para ketua LSM serta masyarakat pemerhati pariwisata Kecamatan Banda.

\section{HASIL DAN ANALISIS}

Identifikasi stakeholders merupakan langkah awal untuk mengetahui berbagai pihak yang berkepentingan serta mengetahui kebutuhan masing-masing stakeholder (Latupapua, 2015; Sulistyanto, 2006). Pada dasarnya, stakeholders dapat diidentifikasi dalam dua sektor yaitu public dan private. Public sector dalam hal ini terdiri dari pemerintah, dalam hal ini pemerintah pusat maupun pemerintah daerah. Sedangkan, private sector yaitu sektor swasta serta masyarakat (Nuryanti \& Hwang, 2002).

Berdasarkan hasil observasi pada lokasi penelitian, stakeholders yang berperan dalam pengelolaan pariwisata Kecamatan Banda dibedakan menjadi 3 yaitu; 1) stakeholder pemerintah, 2) stakeholder swasta 3) masyarakat.

Tabel 1. Identifikasi Stakeholder dan kontribusinya Terhadap Pariwisata Banda

\begin{tabular}{|c|c|}
\hline Stakeholders Pemerintah & Kontribusi terhadap pariwisata Kecamatan Banda \\
\hline Dinas Pariwisata Maluku & Membuat regulasi tentang pengelolaan pariwisata \\
\hline \multirow[t]{2}{*}{ Tengah } & Melakukan promosi pariwisata \\
\hline & Pembangunan infrastruktur penunjang pariwisata \\
\hline Pemerintah Kecamatan & Membuat rencana pembangunan pariwisata \\
\hline \multirow[t]{2}{*}{ Banda } & Melakukan koordinasi dengan stakeholder pariwisata \\
\hline & Membuat regulasi mengenai pariwisata \\
\hline UPTD Pariwisata & Melakukan kontrol terhadap pariwisata \\
\hline Kecamatan Banda & $\begin{array}{l}\text { Menjadi penghubung antara dinas pariwisata Maluku Tengah dengan } \\
\text { masyarakat }\end{array}$ \\
\hline \multirow[t]{3}{*}{ TWP Laut Banda } & Melakukan pengawasan terhadap potensi cagar alam laut Banda \\
\hline & Mengevaluasi efektifitas pengelolaan kawasan \\
\hline & Perlindungan dan pelestarian kawasan wisata laut Banda \\
\hline \multirow[t]{2}{*}{ RSUD Kecamatan Banda } & Melayani kebutuhan wisatawan terkait kesehatan \\
\hline & Menyediakan fasilitas kesehatan bagi wisatawan \\
\hline Stakeholders Swasta & Kontribusi terhadap pariwisata Kecamatan Banda \\
\hline \multirow[t]{3}{*}{ Pengusaha Akomodasi } & Menyediakan sarana akomodasi \\
\hline & Membantu pengelolaan atraksi \\
\hline & Membantu mengembangkan atraksi \\
\hline Yayasan Warisan Budaya & Pengelolaan atraksi \\
\hline \multirow[t]{2}{*}{ Banda } & Bantuan materil untuk pengembangan destinasi \\
\hline & Membantu mengembangkan atraksi \\
\hline \multirow[t]{2}{*}{ Akademisi } & Terlibat dalam pengelolaan pariwisata \\
\hline & Melakukan kajian terkait kepariwisataan \\
\hline Masyarakat & Kontribusi terhadap pariwisata Kecamatan Banda \\
\hline \multirow[t]{3}{*}{ LSM } & Sebagai pendamping masyarakat \\
\hline & Sebagai fasilitator antara masyarakat dengan pemerintah \\
\hline & Menginisiasi kebijakan yang bersifat lokal \\
\hline \multirow[t]{3}{*}{ Masyarakat Umum } & Terlibat dalam pengelolaan dan pengembangan pariwisata \\
\hline & Penyediaan fasilitas wisata \\
\hline & Menikmati manfaat ekonomi dari kehadiran pariwisata \\
\hline
\end{tabular}

Sumber: Hasil olah data penulis, 2019

\section{Peran Pemerintah}

Pemerintah selanjutnya, setelah melakukan identifikasi guna mengetahui detail stakeholder serta perannya, dilakukan pemilihan narasumber yang dianggap mewakili masing-masing stakeholder dalam pengelolaan pariwisata Kecamatan Banda. Pemilihan narasumber dilakukan berdasarkan pertimbangan-pertimbangan dan kapasitasnya dalam institusi maupun sebagai individu dalam masyarakat.

Pemerintah sebagai public sector pada hakikatnya memiliki 3 peran utama sebagaimana dijelaskan oleh Nuryanti dan Hwang (2002), yaitu sebagai perencana kebijakan dan pengatur strategi 
pembangunan, pembentuk lembaga kepariwisataan, serta turut berperan sebagai wirausaha dalam hal pengembangan pariwisata pada tahap awal. Senada dengan Nuryanti, Lickorish dkk (1994) juga menjabarkan peran pemerintah dalam bukunya "Developing Tourism Destinastions". Peran pemerintah yang dituliskan antara lain; sebagai pembuat kebijakan dalam pembangunan pariwisata, melakukan fungsi kontrol termasuk didalamnya perlindungan konsumen, bertindak sebagai koordinator dalam pembentukan forum koordinasi, turut campur tangan dalam kebijakan pajak, menciptakan kenyamanan bagi sektor swasta, melakukan riset terkait pasar wisatawan, melakukan promosi keluar negeri serta bertindak tepat disaat sektor swasta mengalami kegagalan pengembangan destinasi (Lickorish dkk, 1994).

Dalam konteks kepariwisataan Kecamatan Banda, pemerintah dalam hal ini pemerintah pusat adalah sebagai stakeheholder pemerintahan yang memiliki kekuasaan tertinggi. Selanjutnya, pemerintah dengan otoritas dibawah pemerintah pusat adalah pemerintah provinsi yang turut berperan dalam pembangunan kepariwisataan Kecamatan Banda.

1. Pemerintah Sebagai Pembuat Kebijakan

Sebagai pemegang otoritas tertinggi, pemerintah pusat selaku pembuat kebijakan memiliki peran yang sangat penting. Kebijakan yang dihasilkan oleh pemerintah pusat merupakan kebijakan yang akan menentukan perkembangan suatu destinasi. Sejak tahun 2010, terdapat beberapa kebijakan terkait pariwisata yang telah dihasilkan oleh pemerintah, baik pemerintah pusat maupun pemerintah daerah.

Beberapa kebijakan pemerintah pusat yang telah dilakukan dalam rangka pengembangan pariwisata Kecamatan Banda antara lain;

Tabel 2. Regulasi Pemerintah daerah terkait pajak pariwisata

\begin{tabular}{|c|c|}
\hline Tahun & Kebijakan \\
\hline 2009 & Keputusan $\quad$ Presiden \\
\hline & Indonesia Nomor 35 Tahun 2009 \\
\hline & Penyelenggaraan \\
\hline
\end{tabular}

2010 Rencana Induk Pembangunan Kepariwisataan Nasional Tahun 2010-2025

2011 Masterplan Percepatan dan Perluasan Pembangunan Ekonomi Indonesia (MP3EI)

2014 Perubahan atas Undang-Undang Nomor 27 Tahun 2007 Tentang Pengelolaan Wilayah Pesisir dan Pulau-Pulau Kecil.

2015 Pengajuan Banda Sebagai world heritage center oleh KWRI dengan nama

2015 Rencana Tata Ruang Kawasan Perbatasan Negara di Provinsi Maluku

2017 Rencana Kerja Tahunan (RKT) Kabupaten Maluku Tengah

Keterangan

Keputusan Presiden menetapkan penyelenggaraan event Sail Banda 2010. Salah satu tujuan dari pelaksanaan event internasional tersebut adalah untuk memperbaiki citra Maluku pasca konflik serta membuktikan bahwa Maluku dan sekitarnya memiliki potensi wisata yang banyak sehingga layak untuk dikunjungi.

Dalam Rencana Induk Pembangunan Kepariwisataan Nasional Tahun 2010 Bandaneira dan sekitarnya termasuk dalam Destinasi Pariwisata Nasional. Selain itu, Bandaneira juga termasuk dalam Kawasan Pengembangan Pariwisata Nasional (KPPN).

Kecamatan Banda ditetapkan sebagai lokasi potensial golden fishing ground atau potensi perikanan dalam kawasan ekonomi Papua-Maluku.

Perubahan Cagar Alam Laut menjadi Taman Wisata Perairan Laut Banda.

Banda diajukan oleh Kantor Wakil Republik Indonesia untuk UNESCO (KWRI UNESCO, atau Kantor Delegasi Tetap RI untuk UNESCO) untuk menjadi salah satu world heritage center. Saat ini Banda masuk dalam salah satu tentative list.

Dalam Peraturan Presiden nomor 33 tahun 2015, Banda termasuk dalam zona L6 yaitu zona biota laut yang dilindungi, dan zona A1 yang didalamnya termasuk perlindungan ekosistem.

Pariwisata menjadi salah satu sektor prioritas pembangunan daerah.

Sumber: Hasil observasi penulis, 2019 
2. Pemerintah Sebagai Pembuat Regulasi Pajak

Lickorish dkk (1994), menyatakan bahwa membuat regulasi terkait pajak merupakan salah satu fungsi esensial pemerintah. Fungsi pemerintah dalam pembuatan regulasi pajak diatur oleh undang-undang. Pajak pada dasarnya memiliki peranan yang fundamental dalam suatu negara karena pajak merupakan salah satu sumber pendapatan negara.

Dalam lingkup kepariwisataan nasional, Direktorat Jenderal Pajak dan Kementerian Pariwisata telah membuat regulasi terkait pajak nasional dalam bidang pariwisata antara lain; PP No. 18 Tahun 2015 tentang Fasilitas Pajak Penghasilan Untuk Penanaman Modal di BidangBidang Usaha Tertentu dan/ atau di Daerah-Daerah Tertentu dan Peraturan Menteri Pariwisata No. 9 Tahun 2015 tentang Kriteria dan/atau Persyaratan Pemanfaatan Fasilitas Pajak Penghasilan Untuk Penanaman Modal di Bidang Usaha Kawasan Pariwisata. Regulasi pajak terkait dibuat guna mengatur penerimaan negara pada sektor pariwisata.

Pada lingkup pemerintah Kabupaten Maluku Tengah, regulasi terkait pajak, terutama dalam bidang pariwisata tertuang dalam peraturan daerah maupun peraturan bupati. Terdapat beberapa regulasi yang dibuat pemerintah khususnya pemerintah Kabupaten Maluku Tengah tekait regulasi pajak dalam bidang pariwisata:

Tabel 3. Regulasi Pemerintah daerah terkait pajak pariwisata Regulasi Keterangan

Peraturan Daerah Kabupaten Maluku Perda terkait mengatur tentang pajak dan retribusi daerah melalui Tengah nomor 17 tahun 2012.

Peraturan Bupati Maluku Tengah nomor 29 tahun 2018.

Peraturan Daerah Kabupaten Maluku Perda ini mengatur tentang pajak restoran yaitu 10\%.

Tengah nomor 19 tahun 2009.

Peraturan Daerah Kabupaten Maluku Peraturan ini memuat tentang retribusi tempat Tengah nomor 22 tahun 2012 . menginap/penginapan/pesanggrahan/vila Peraturan Daerah Kabupaten Maluku Memuat tentang retribusi tempat rekreasi dan olahraga. Tengah nomor 23 tahun 2012.

Sumber: Hasil observasi penulis, 2019

Pemerintah sebagai pembuat regulasi pajak pada lingkup Kabupaten Maluku Tengah telah berperan aktif ditinjau dari jumlah dan lingkup regulasi pajak dalam bidang pariwisata. pada pelaksanaanya, terdapat beberapa hal mendasar terkait pajak yang belum maksimal pelaksaanaanya. Sebagai contoh, pelaksanaan dari Perda nomor 17 tahun 2012 tentang pajak hotel yaitu 10\%. Hal ini dirasa berat oleh beberapa pengusaha akomodasi, pemerintah dinilai belum meilbatkan masyarakat dalam pembuatannya serta tingginya pajak tidak berimbang dengan pembangunan yang dilakukan oleh Pemerintah Kabupaten Maluku Tengah terhadap kepariwisataan Kecamatan Banda.

3. Pemerintah sebagai agen promosi wisata keluar negeri

Promosi merupakan salah satu aspek pokok dalam pariwisata guna pengembangan serta memperkenalkan sebuah destinasi bagi wisatawan. Pemerintah dalam konteks ini memiliki peran yang sentral sebagai agen promosi. Pemerintah dengan kekuatan jaringan dan diplomasinya memiliki dapat dimanfaatkan sebagai sebuah keuntungan guna memperkenalkan sebuah destinasi.

Sebagai salah satu destinasi prioritas provinsi Maluku, destinasi wisata Kecamatan Banda telah beberapa kali diikutsertakan dalam promosi yang dilakukan oleh pemerintah, dalam hal ini pemerintah pusat yaitu Kementerian Pariwisata. Promosi yang dilakukan pada umumnya diinisiasi oleh Kementerian Pariwisata dan melibatkan pelaku-pelaku wisata yang terdapat di Kecamatan Banda. Berikut disajikan data terkait kegiatan promosi yang dilakukan poemerintah pusat berdasarkan hasil wawancara dengan pihak dinas pariwisata Kabupaten Maluku Tengah serta hasil observasi peneliti.

Tabel 4. Kegiatan Promosi Destinasi Wisata Kecamatan Banda ke Luar Negeri

\begin{tabular}{llrl}
\hline Tahun & Kegiatan & \multicolumn{1}{c}{ Keterangan } \\
\hline 2016 & Promosi & Dive & Pada acara ini, kementerian pariwsata mempromosikan potensi kelautan \\
& "Dive Wonderful & indonesia, salah satunya Banda. Perwakilan dari Banda dalam acara ini adalah \\
& Indonesia' & pada & Nutmeg Tree Dive Banda Neira serta dinas pariwisata provinsi Maluku. \\
\hline
\end{tabular}




\begin{tabular}{|c|c|c|}
\hline & $\begin{array}{lr}\text { acara } & \text { MIDE } \\
\text { (Malaysia } & \text { Dive } \\
\text { Expo) 2016 } & \end{array}$ & $\begin{array}{l}\text { Dengan tema Divers Heaven One Nation in Wonderful Indonesia, acara } \\
\text { promosi ini diharapkan mampu memperkenalkan wisata diving Indonesia } \\
\text { dimata dunia }\end{array}$ \\
\hline 2017 & $\begin{array}{l}\text { Pameran ITB } \\
\text { (Internationale } \\
\text { Tourismus-Börse } \\
\text { Berlin) di Berlin. }\end{array}$ & $\begin{array}{l}\text { Pada pameran yang ini, pariwisata Kecamatan Banda diperkenalkan oleh dinas } \\
\text { pariwisata provinsi Maluku. Pada kesempatan tersebut, pariwisata Kecamatan } \\
\text { Banda dipromosikan melalui brosur dan leaflet yang berisi informasi } \\
\text { mengenai pariwisata Kecamatan Banda. Pameran ini diprakarsai oleh } \\
\text { Kemenenterian Pariwisata Republik Indonesia. }\end{array}$ \\
\hline 2018 & $\begin{array}{l}\text { Pameran } \\
\text { Pariwisata } \\
\text { Vakantiebeurs di } \\
\text { Belanda }\end{array}$ & $\begin{array}{l}\text { Pada pameran ini, Banda merupakan salah satu destinasi yang dipromosikan. } \\
\text { Pameran ini diselenggarakan oleh Kementerian Pariwisata Republik } \\
\text { Indonesia, dengan tujuan agar mendongkrak wisatawan mancanegara terutama } \\
\text { wisatawan asal Belanda dan Eropa. }\end{array}$ \\
\hline 2019 & $\begin{array}{lr}\text { Asia Dive } & \text { Expo } \\
\text { (Adex) } & \text { di } \\
\text { Singapura }\end{array}$ & $\begin{array}{l}\text { Pada pameran ini, Kementerian Pariwisata memperkenalkan } 86 \text { spot diving } \\
\text { terbaik di indonesia. Dalam pameran ini, indonesia melalui Kementerian } \\
\text { Pariwisata memperkenalkan } 10 \text { destinasi prioritas diving, salah satunya adalah } \\
\text { Banda Neira. Perwakilan dari Kecamatan Banda yang ikut serta dalam } \\
\text { pameran ini adalah Blue Motion Dive Center Banda. }\end{array}$ \\
\hline
\end{tabular}

Sumber: Hasi observasi penulis, 2019

\section{Peran Swasta}

Sektor swasta dalam pariwisata pada umumnya berorientasi pada keuntungan finansial atau profit (Ellena, 2012; Nuryanti, 2002). Sektor swasta tidak memiliki kepentingan politik yang formal, namun memiliki kebutuhan sendiri dalam hal pengembangan pariwisata. Peran sektor swasta dalam pengembangan pariwisata lebih fleksibel karena memiliki keunggulan modal (Nuryanti dan Hwang, 2002).

Sektor swasta memiliki 5 peran dalam pengembangan destinasi pariwisata sebagaimana dijelaskan oleh Lickorish dkk (1994). Peran sektor swasta yang digambarkan Lickorish antara lain; sebagai penyedia akomodasi, souvenir, sarana hiburan, sarana pendukung transportasi serta turut berperan dalam pengembangan atraksi wisata. Senada dengan Lickorish, Udumo (2013) menyatakan bahwa peran sektor swasta dalam pariwisata antara lain sebagai penyedia modal, akomodasi, sarana hiburan, transportasi serta sebagai pendukung pembangunan infrastruktur. Dalam konteks kepariwisataan Kecamatan Banda, saat ini terdapat beberapa aktor swasta yang berperan antara lain; pengusaha akomodasi, Yayasan Warisan Budaya Banda dan beberapa dive center yang terdapat di Kecamatan Banda. Sektor swasta yang berperan dalam kepariwisataan Kecamatan Banda pada umumnya adalah penduduk asli Kecamatan Banda. Hingga saat ini belum ada investor atau pihak swasta dari luar Kecamatan Banda yang berperan dalam pengembangan kepariwisataan.

1. Sektor swasta sebagai penyedia infrastruktur akomodasi

Peran sektor swasta dalam penyediaan sarana akomodasi di Kecamatan Banda telah dilakukan, hal ini dapat dilihat dari ketersediaan 220 sarana akomodasi berupa hotel, penginapan dan homestay yang tersebar kepulauan yang ada di Kecamatan Banda. Sarana akomodasi dangan skala yang lebih besar berupa resort, saat ini belum tersedia di Kecamatan Banda. Persebaran akomodasi masih terpusat di kota Neira, saat ini terdapat 118 sarana akomodasi berupa hotel, penginapan dan homestay yang terdapat di kota Neira. Akomodasi lain yang berlokasi di luar kota Neira pada umumnya berupa homestay dan penginapan.
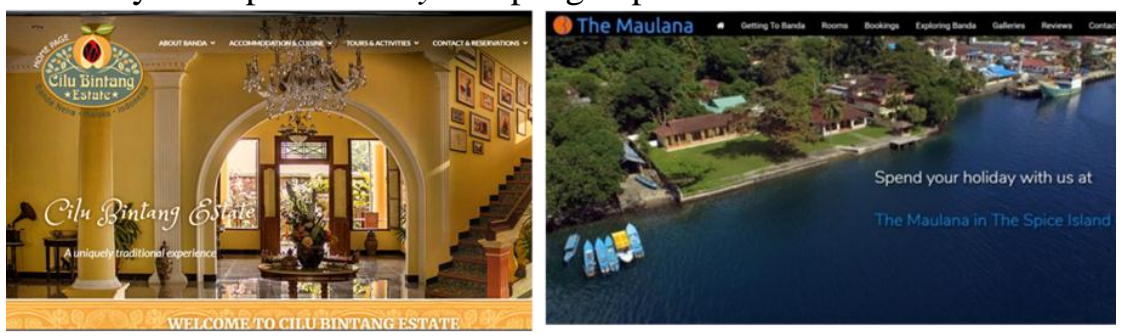

Gambar 2. Penyediaan Akomodasi oleh Sektor Swasta.

The Maulana Hotel (kiri), Cilu Bintang Estate (kanan).

Sumber: Website penyedia akomodasi terkait 
2. Sektor swasta sebagai pendukung pengembangan atraksi

Peran sektor swasta selain sebagai penyedia akomodasi, sektor swasta juga berperan sebagai pendukung pengembangan atraksi. Saat ini, peran sektor swasta dalam pengembangan atraksi wisata telah terlihat, baik melalui program Corporate Social Resposibility (CSR) maupun pengembangan atraksi secara parsial oleh swasta.

Peran sektor swasta dalam program CSR terlihat pada pengembangan beberapa atraksi, terutama di pulau Banda Besar dan pulau Neira. Program CSR terbaru yaitu pengecatan beberapa atraksi di pulau Banda Besar dan Kota Neira. Program CSR ini melibatkan kerjasama antara pemerintah Kecamatan Banda Bank BRI dan PT. Pacific Paint.
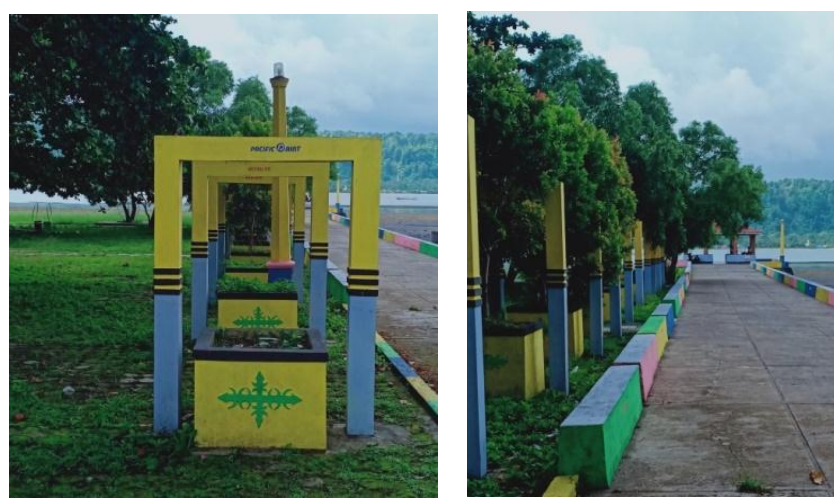

Gambar 3. Wujud kerjasama program CSR dalam pengembangan pariwisata kecamatan Banda. Sumber: Dokumentasi penulis, 2019

Selain program CSR, sektor swasta yang berperan dalam pengembangan atraksi adalah Yayasan Warisan Budaya Banda. Beberapa upaya yang telah dilakukan antara lain; pembentukan rumah budaya Banda sebagai museum, pemugaran rumah-rumah pengasingan serta promosi destinasi yang dilakukan oleh Yayasan Warisan Budaya Banda baik skala nasional maupun internasional.

Saat ini, rumah-rumah pengasingan para tokoh pejuang kemerdekaan Indonesia yang terdapat di Kecamatan Banda dimiliki dan dikelola penuh oleh Yayasan Warisan Budaya. Sebagai contoh, rumah pengasingan Bung Hatta, rumah pengasingan Iwa Koesoemasoemantri dan rumah pengasingan Sutan Sjahrir, semuanya terdaftar dalam sistem registrasi cagar budaya nasional dan dikelola oleh Yayasan Warisan Budaya Banda.

\section{^ RUMAH PENGASINGAN BUNG HATTA}
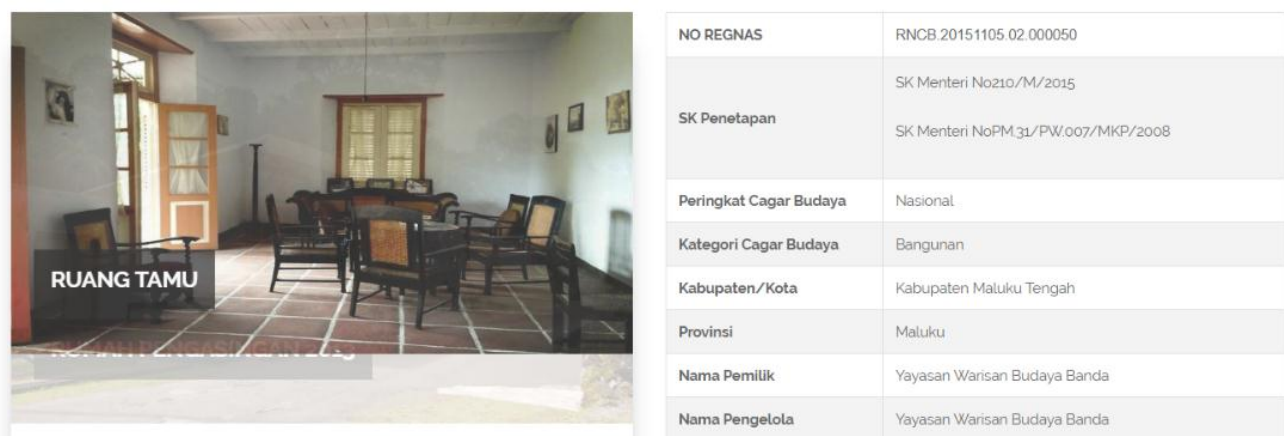

Gambar 4. Rumah pengasingan Bung Hatta

Sumber: Website Kemendikbud, 2019

\section{Peran Masyarakat}

Peran aktif masyarakat kecamatan banda sudah terlihat dalam 5 tahun terakhir. Masyarakat Kecamatan Banda mulai terlibat dalam pembentukan LSM, penyediaan fasilitas pariwisata, serta turut berperan aktif dalam pengembangan atraksi. Saat ini terdapat 3 LSM yang bergerak dalam bidang pariwisata di Kecamatan Banda yaitu: 
1. LSM Parduli Negeri

LSM Parduli Negeri (peduli negeri) berdiri pada tahun 2014. LSM Parneg beranggotakan anak muda Banda yang peduli tehadap negeri. Pada tahun 2018, jumlah anggota aktif LSM Parduli negeri adalah 18 orang. Terbentuknya LSM Parneg bertujuan membantu pemerintah terutama dalam hal kebersihan lingkungan.

2. LSM Buka Mata

LSM Bukamata adalah salah satu LSM di Kecamatan Banda yang berdiri pada tanggal 8 Agustus 2018. Sama seperti LSM Parduli Negeri, LSM Buka Mata juga dibentuk untuk meningkatkan kepedulian masyarakat akan kebersihan lingkungan, menegakan kemandirian ekonomi, serta melindungi nilai tradisi yang ada di Kecamatan Banda.

3. LSM Kelompok Kreatif Anak Banda (KKAB)

Kelompok Kreatif Anak Banda (KKAB) awal berdirinya diinisiasi oleh Magafira Ali yang juga merupakan ketua KKAB. LSM ini berdiri pada tahun 2014. Awal berdirinya KKAB berdasarkan keprihatinan terhadap kondisi sampah plastik yang ada di Kecamatan Banda akibat aktifitas pariwisata. Anggota LSM KKAB kebanyakan terdiri dari guru, sarjana serta para pemuda yang dinilai mampu mengedukasi masyarakat tentang daur ulang sampah.

\section{Kolaborasi peran stakeholders}

Peran stakeholders dari setiap sektor dalam konteks kepariwisataan Kecamatan Banda tidak sepenuhnhya parsial. Terdapat program-program hasil kolaborasi stakeholders dari sektor swasta, pemerintah maupun masyarakat. Program-program strategis tersebut bertujuan untuk pengembangan destinasi pariwisata Kecamatan Banda. Program pengembangan destinasi yang dipaparkan dibawah ini adalah program pengembangan yang dilakukan sejak tahun 2010 hingga tahun 2019.

Tabel 5. Program Hasil Kolaborasi Stakeholders Terkait Kepariwisataan Kecamatan Banda

\begin{tabular}{|c|c|c|}
\hline Nama Program & Tahun & Pelaksana \\
\hline Sail Banda & 2010 & $\begin{array}{l}\text { Pemerintah Pusat, Kementerian Kelautan dan Perikanan, } \\
\text { Yayasan Warisan Budaya Banda }\end{array}$ \\
\hline Festival Budaya Banda & $\begin{array}{l}2011- \\
2019\end{array}$ & $\begin{array}{l}\text { Dinas Pariwisata Provinsi Maluku, Dinas Pariwisata Kabupaten } \\
\text { Maluku Tengah }\end{array}$ \\
\hline Banda Sea Inner Arc & 2012 & $\begin{array}{l}\text { Kementerian Kelautan dan Perikanan, LIPI, Universitas } \\
\text { Pattimura, Yayasan Warisan Budaya Banda Naira, Marine } \\
\text { Conservation Southeast Asia. }\end{array}$ \\
\hline $\begin{array}{l}\text { Penetapan Bangunan Cagar } \\
\text { Budaya Banda Neira }\end{array}$ & 2015 & $\begin{array}{l}\text { Kementerian Pendidikan dan Kebudayaan, Yayasan Warisan } \\
\text { Budaya Banda }\end{array}$ \\
\hline Wonderfull and Amazing Banda & 2016 & Himpunan Pengusaha Muda, Indonesia Kementerian Pariwisata \\
\hline $\begin{array}{l}\text { Pembentukan } \\
\text { ekowisata } \\
\text { berbasis tanaman pala di } \\
\text { Kecamatan Banda }\end{array}$ & 2016 & $\begin{array}{l}\text { Direktorat Jenderal Perkebunan Kementan, Dinas Pertanian } \\
\text { Maluku }\end{array}$ \\
\hline Banda Warisan untuk Indonesia & 2017 & $\begin{array}{l}\text { Yayasan Warisan Budaya Banda, Kementerian Pendidikan dan } \\
\text { Kebudayaan }\end{array}$ \\
\hline $\begin{array}{l}\text { Seminar Peringatan } 350 \text { Tahun } \\
\text { Perjanjian Breda }\end{array}$ & 2017 & $\begin{array}{l}\text { Dinas Kebudayaan, Pemerintah Propinsi, Yayasan Warisan } \\
\text { Budaya Banda }\end{array}$ \\
\hline Baktiku Negeriku & 2017 & Telkomsel, TNI \\
\hline Pesta Rakyat Banda & 2018 & $\begin{array}{l}\text { Dinas Pariwisata Provinsi Maluku, Dinas Pariwisata Kabupaten } \\
\text { Maluku Tengah, Pemerintah Kecamatan Banda. }\end{array}$ \\
\hline $\begin{array}{l}\text { Pengecatan atraksi wisata di } \\
\text { negeri Lonthoir }\end{array}$ & 2018 & Bank BI, Pemerintah Kecamatan Banda, LSM \\
\hline
\end{tabular}

Sumber: Hasil observasi penulis, 2019

\section{Implementasi Peran Stakeholders}

Berpedoman pada hasil identifikasi stakeholders, deskripsi posisi dan derajat kepentingan, dilakukan evaluasi pelaksanaan peran berdasarkan fungsi yang telah diidentifikasi sebelumnya. Hasil analisis implementasi peran stakeholders disajikan pada tabel dibawah ini: 
Tabel 6. Evaluasi peran stakeholders dalam pengembangan pariwisata Kecamatan Banda

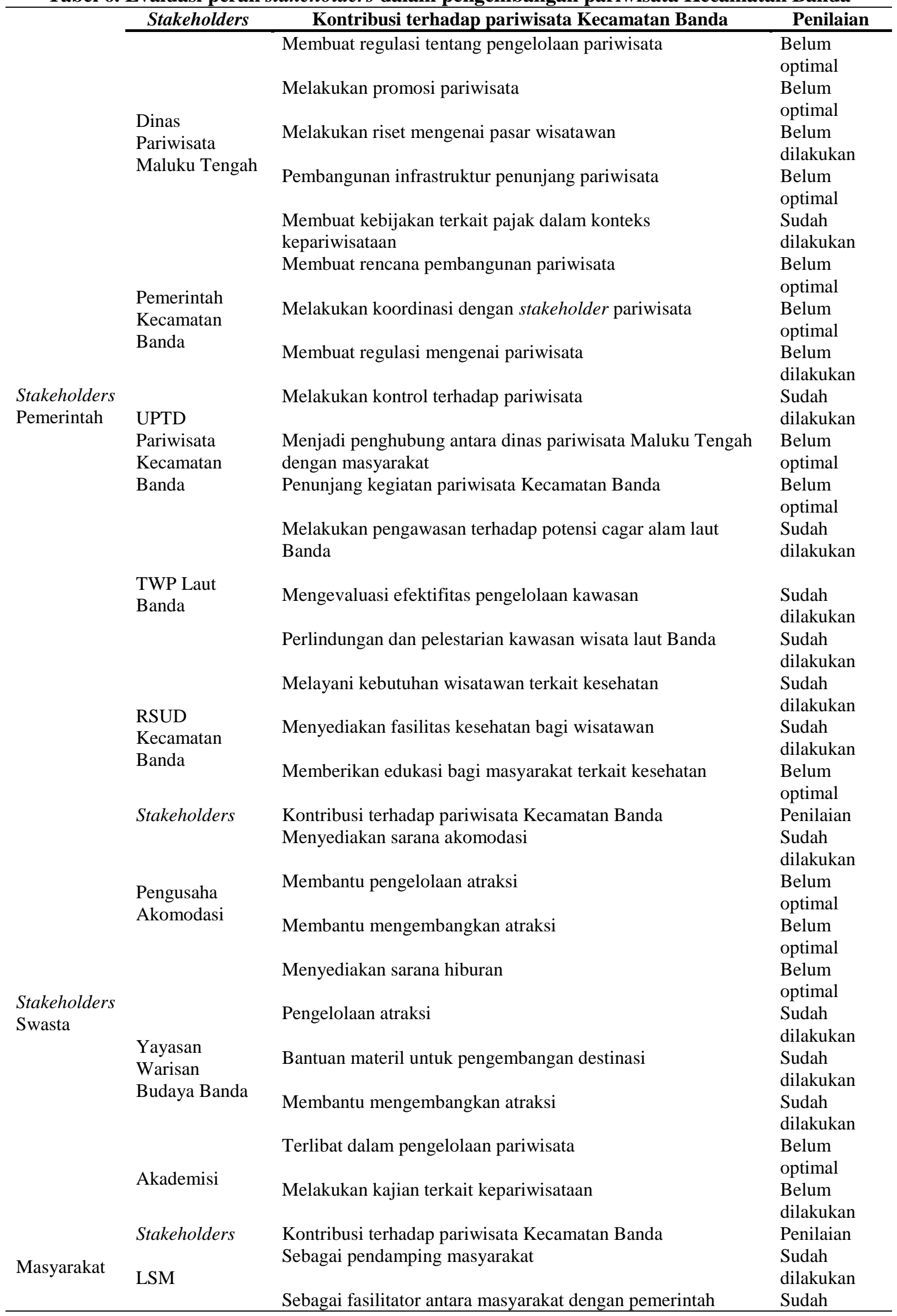




$\begin{array}{lll} & \text { Menginisiasi kebijakan yang bersifat lokal } & \text { dilakukan } \\ & \text { Terlibat dalam pengelolaan dan pengembangan pariwisata } & \begin{array}{l}\text { Sudah } \\ \text { dilakukan }\end{array} \\ & & \begin{array}{l}\text { Belum } \\ \text { optimal }\end{array} \\ \text { Masyarakat } & \text { Penyediaan fasilitas wisata } & \text { Sudah } \\ \text { Umum } & \text { Menikmati manfaat ekonomi dari kehadiran pariwisata } & \begin{array}{l}\text { Sudah } \\ \text { dilakukan }\end{array} \\ & & \end{array}$

Sumber: Hasil analisis penulis, 2019

\section{Dampak Dari Implementasi Peran Stakeholders}

Perencanaan pembangunan pariwisata Kecamatan Banda belum sepenuhnya berjalan. Terdapat berbagai kendala yang muncul sebagai akibat dari kurangnya koordinasi antar stakeholders. Sebagai contoh, program CSR antara Bank Indonesia dan pemerintah Kecamatan Banda. Program yang dilakukan adalah pengecatan rumah warga dalam upaya membuat desa warna-warni pada desa Lonthoir. Kurangnya koordinasi mengakibatkan program yang direncanakan tidak berjalan dengan baik. Rencana awalnya yaitu pengecatan rumah warga, namun pada kenyataanya yang dicat adalah tangga tua desa Lonthoir yang telah berumur ratusan tahun. Tangga tua yang dibangun pada abad ke17 tersebut dicat warna-warni sehingga menimbulkan protes dari berbagai kalangan. Kadir Sarilan sebagai Camat Kecamatan Banda menyampaikan;

'Awalnya dalam proposal itu pengecatan rumah warga, bukan tangga. Karena kurang koordinasi akhirnya dong (mereka) cat tangga. Katong (kami) sudah minta dong stop pengecatan, tetapi dong masih terus lanjut cat tangga itu. Intinya tidak pernah ada ijin untuk pengecatan tangga tersebut'
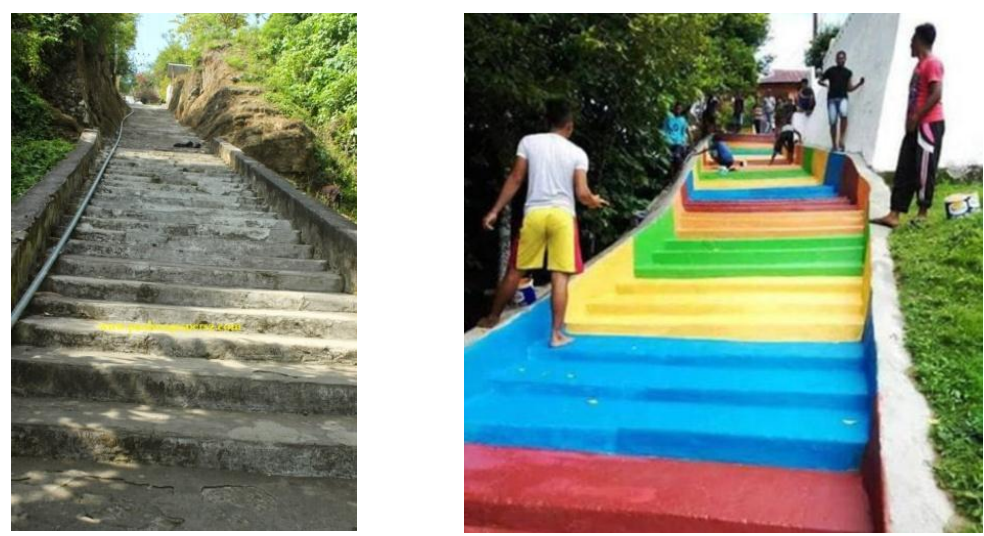

Gambar 4. Potret tangga tua desa Lonthoir. Sebelum dicat (kiri), setelah dicat (kanan). Sumber: Dokumentasi penulis, 2019

Kendala lainnya yang terlihat adalah terkait pembangunan atraksi, dalam hal ini pemugaran benteng peninggalan kolonial, yaitu benteng Nassau. Pemugaran ini dilakukan oleh Kementerian Pendidikan dan Kebudayaan Republik Indonesia. Pemugaran benteng Nassau menelan biaya 1,3 Miliar dan digarap oleh Balai Pelestarian Cagar Budaya Ternate, Provinsi Maluku Utara dan melibatkan CV. Nur Sejati selaku penyedia jasa. Pemugaran tahap pertama dilakukan pada tahun 2015, tahap kedua dilakukan pada tahun 2018. Permasalahan yang muncul adalah penggunaan material pada pemugaran benteng Nassau yang tidak sesuai dan terkesan asal-asalan. Hal ini menimbulkan protes dari masyarakat maupun akademisi, seperti yang disampaikan oleh tokoh masyarakat, Abah Rizal;

'Benteng ini yang perbaiki BPCB Ternate, dong (mereka) membangun tidak memperhatikan keadaan sekitar. Bahan yang dong pakai itu semen dan cor-corannya asalasalan. Perbaikannya juga seng (tidak) ada pelibatan masyarakat, dong bangun sandirisandiri. Benteng sekarang sudah kelihatan beda dengan yang dolo (dulu)'. 
Secara garis besar disampaikan oleh Abah Rizal bahwa pembangunan kembali benteng Nassau tidak dikoordinasikan dengan masyarakat sehingga pembangunanya tidak sesuai serta penggunaan material yang tidak tepat mengurangi citra Nassau sebagai benteng peninggalan Kolonial.
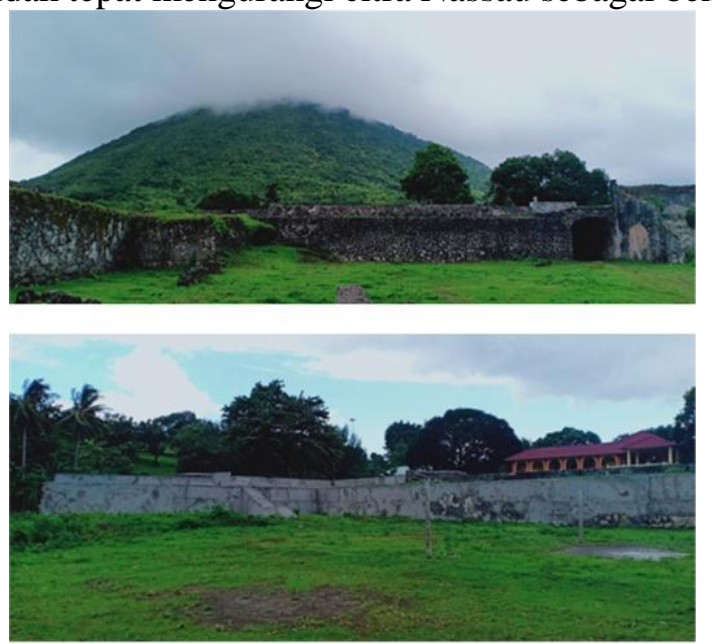

Gambar 5. Dua sisi berbeda dari benteng Nassau.

Tidak/belum dipugar (atas), sisi lain yang sudah dipugar (bawah).

Sumber: Dokumentasi penulis, 2019

Sektor swasta ditinjau dari perannya, terlihat dominan dalam konteks kepariwisataan Kecamatan Banda. Pada tabel 5, dari total 11 program pengembangan 6 diantaranya melibatkan sektor swasta. Beberapa program esensial diinsiasi oleh sektor swasta dalam upaya pengembangan pariwisata. Peran sektor swasta yang dominan dalam hal ini adalah Yayasan Warisan Budaya Banda.

Pemerintah dalam hal ini pemerintah Provinsi Maluku, pemerintah Kabupaten Maluku Tengah serta pemerintah Kecamatan Banda belum menunjukan peran yang signifikan dalam menjalankan fungsinya. Sektor pemerintah yang terlihat perannya hanya pemerintah pusat dalam hal ini kementerian baik Kementerian Pariwisata, Kementerian Kelautan dan Perikanan serta Kementerian Pendidikan dan Kebudayaan sebagaimana tergambarkan dalam tabel 5.

Hampton \& Jeyacheya (2015), dalam penelitiannya yang berjudul Power, Ownership and Tourism in Small Islands: Evidence from Indonesia mengemukakan bahwa pariwisata Kepulauan di Indonesia beberapa diantaranya berkembang secara organik. Perkembangan organik yang dimaksud adalah perkembangan pariwisata tanpa arah yang strategis serta tanpa dukungan dari pemerintah baik pemerintah pusat maupun pemerintah daerah. Selanjutnya dijelaskan juga bahwa pariwisata yang dikembangakan secara organik cenderung homogen dan didalamnya berlaku hukum tradisional (adat) dalam hal kepemilikan serta penggunaan lahan. Hal ini jelas terlihat pada destinasi pariwisata Kecamatan Banda sebagai destinasi wisata Kepulauan dimana pariwisata berkembang secara organik, minim diversifikasi serta masih berlakunya hukum tradisional.

Realitas hukum adat masyarakat Kecamatan Banda tampak dari model-model komunikasi internal. Bungin (2010), membagi model komunikasi lokal Orang Banda dalam 3 tipe komunikasi yaitu; komunikasi memusat pada Des Alwi, memusat pada tokoh lain, dan memusat pada tokoh adat atau formal. Seperti yang telah dijelaskan sebelumnya bahwa Des Alwi merupakan salah satu tokoh Banda yang memiliki pengaruh besar dalam perkembangan pariwisata Kecamatan Banda. Des Alwi adalah pendiri Yayasan Warisan Budaya Banda. Des Alwi memiliki kekuatan tinggi baik dari segi politik, sosial serta materil. Berdasarkan temuan Bungin mengenai model komunikasi, pada fase development pariwisata Kecamatan Banda komunikasi antar stakeholder pada lingkup Kecamatan Banda pada umumnya berpusat kepada Des Alwi. Hal ini menjadikan Des Alwi tokoh sentral dalam pengembangan pariwisata Kecamatan Banda. Dengan kekuatan lobi tingkat nasional bahkan internasional, sebagian besar dari keputusan pembangunan kepariwisataan Kecamatan Banda dihasilkan di Jakarta, bukan di Maluku atau Maluku Tengah sebagai kabupaten dimana Kecamatan Banda bernaung. Des Alwi sebagai tokoh sentral dan berposisi sebagai individu pada sektor swasta 
memiliki peran yang dominan terhadap pembangunan pariwisata Kecamatan Banda. Hal yang sama juga terlihat pada Yayasan Warisan Budaya Banda sebagaimana dijelaskan diatas.

Sepeninggalan Des Alwi, saat ini Yayasan Warisan Budaya Banda dikelola oleh Tanya Alwi, putri dari Des Alwi. Sejak tahun 2010 Yayasan Warisan Budaya masih terus berperan aktif dalam pengembangan kepariwisataan Kecamatan Banda terutama dalam pelaksanaan event pariwisata sebagaimana tergambarkan dalam tabel 5 .

\section{KESIMPULAN}

Peran masing-masing pemangku kepentingan umumnya sudah berjalan, tetapi beberapa dari mereka tidak maksimal. Peran dan upaya pemerintah sebagai pemegang otoritas yang legal belum optimal sehingga mempengaruhi sektor swasta. Upaya Pemerintah umumnya bertujuan untuk mendatangkan wisatawan melalui acara dan pameran. Upaya pemerintah untuk mendatangkan wisatawan melalui ajang tersebut belum berdampak maksimal terhadap destinasi wisata Kabupaten Banda, karena faktanya jumlah kunjungan wisatawan akan kembali turun paska event. Kurangnya repeatable tourism menjadi gambaran bahwa belum optimalnya peran pemerintah daerah. Selain itu, peran pemerintah hingga saat ini belum inklusif, terutama pada pengembangan objek wisata dan penyediaan infrastruktur pariwisata. Peran sektor privat terlihat cukup dominan dari upaya menyediakan akomodasi, pengembangan daya tarik, dan upaya promosi. Sektor swasta berperan aktif dalam berbagai upaya pengembangan pariwisata di Kabupaten Banda. Peran masyarakat di Kecamatan Banda mulai terlihat dalam 5 tahun terakhir ditinjau dari keterlibatan masyarakat dalam pariwisata.

Saat ini perlu adanya kerjasama yang maksimal antar semua stakeholder Kecamatan Banda. Dengan kekayaan potensi wisata alam, potensi wisata budaya serta potensi wisata kepulauan yang ada di Kepulauan Banda, perlu adanya program kerjasama yang baik antar semua pemangku kebijakan. Dalam bukunya yang berjudul Private and public sector partnership in tourism development, Nuryanti (2002), telah menjelaskan dengan detil program kerjasama yang dimaksud sehingga buku tersebut dapat dijadikan panduan bagi pemerintah kabupaten maupun pemerintah kecamatan untuk melaksanakan program Public Private Partnership (P3).

\section{DAFTAR RUJUKAN}

Bjärstig, T., \& Sandström, C. (2017). Public-private partnerships in a Swedish rural context - A policy tool for the authorities to achieve sustainable rural development? Journal of Rural Studies, 49, 58-68. https://doi.org/10.1016/j.jrurstud.2016.11.009

Bungin, B. (2010). Destinasi Banda Neira: brand pariwisata Indonesia Timur : sejarah masa lalu, kekayaan Maluku masa kini, dan dinamika Bandanese. Prenada Media Group.

Creswell, J. W. (2013). Research Design Pendekatan Penelitian Kualitatiif, Kuantitatif, dan Mixed, 1308.

Creswell, J. W. (2014). Research design: qualitative, quantitative, and mixed methods approaches (4th ed). Thousand Oaks: SAGE Publications.

Crosby, B. C., \& Bryson, J. M. (1992). Leadership for the Common Good (1st ed.). San Francisco: John Wiley \& Sons.

Freeman, R. E. (1984). Strategic management: A stakeholder approach. Strategic Management: A Stakeholder Approach. https://doi.org/10.1017/CBO9781139192675

Goeldner, C. R., \& Ritchie, J. R. B. (2012). Tourism: principles, practices, philosophies (12th ed). Hoboken, NJ: Wiley.

Hampton, M. P., \& Jeyacheya, J. (2015). Power, Ownership and Tourism in Small Islands: Evidence from Indonesia. World Development, 70, 481-495.

https://doi.org/10.1016/j.worlddev.2014.12.007 
Latupapua, Y. (2015). Implementasi Peran Stakeholder Dalam Pengembangan Ekowisata Di Taman Nasional Manusela (Tnm) Di Kabupaten Maluku Tengah. Jurnal Agroforestri.

Lickorish, L., Jefferson, A., Bodler, J., \& Jenkins, C. (1994). Developing Tourism Destination. Great Britain: Longman Group UK.

Nuryanti, W., \& Hwang, W.-G. (2002). Private and public sector partnership in tourism development. Yogyakarta: Gadjah Mada University Press.

Parmar, B. L., Freeman, R. E., Harrison, J. S., Wicks, A. C., Purnell, L., \& de Colle, S. (2010). Stakeholder Theory: The State of the Art. The Academy of Management Annals, 4(1), 403-445. https://doi.org/10.1080/19416520.2010.495581

Savage, G. T., Nix, T. W., Whitehead, C. J., \& Blair, J. D. (1991). Strategies for assessing and managing organizational stakeholders. Executive, 5(2), 61-75. https://doi.org/10.5465/ame.1991.4274682

Sulistyanto, B. (2006). Resolusi Konflik Pemanfaatan Sumber Daya Arkeologi di Indonesia: Suatu Kerangka Konseptual. Pusat Penelitian Dan Pengembangan Arkeologi Nasional.

Udumo, B., $\alpha$, B. O., $\sigma$, A., \& Authors $\alpha \sigma \rho$, $\rho$. (2013). Public and Private Sector Participation and Tourism Development in Cross River State, Nigeria Public and Private Sector Participation and Tourism Development in Cross River State, Nigeria Public and Private Sector Participation and Tourism Development in. Global Journal of Science Frontier Research Interdisciplinary, $13(1), 0-6$.

UNWTO. (2018). 2018 Edition UNWTO Tourism Highlights, 1-20. https://doi.org/DOI: https://doi.org/10.18111/9789284419876

Weaver, D., \& Lawton, L. (2010). Tourism Management. Australia: John Wiley \& Sons.

William C. Gartner. (1996). Touism Development: Principles, Processes, and Policies. John Wiley \& Sons.

Williams, P. W., Penrose, R. W., \& Hawkes, S. (1998). Shared decision-making in tourism land use planning. Annals of Tourism Research, 25(4), 860-889. https://doi.org/10.1016/S01607383(98)00037-1

Wrangham, R. (1999). Management or domination? Planning tourism in the Banda Islands, Eastern Indonesia. International Journal of Contemporary Hospitality Management, 11(2-3), 111-115. https://doi.org/10.1108/09596119910251011

WTCC. (2019). Travel and Tourism Economic Impact 2019. 